\title{
OLHARES DE VIGILÂNCIA CONTRA OS CRISTÃOS-NOVOS ANTES E DURANTE A PRIMEIRA VISITAÇÃO DA INQUISIÇÃO À CAPITANIA DE PERNAMBUCO
}

\author{
Priscila Gusmão Andrade* \\ Juciene Ricarte Apolinário**
}

\begin{abstract}
RESUMO: O presente artigo analisa a presença dos cristãos-novos na Capitania de Pernambuco ao longo do século XVI. A partir das denunciações que resultaram da Primeira Visitação da Inquisição ao Brasil, e a presença do visitador na Capitania supracitada, entre os anos de 1593 a 1595, procura-se perceber como se davam os olhares de vigilância sobre os cristãos-novos por parte da população de cristãos-velhos, desde antes da chegada do representante do tribunal por essas terras. Mesmo que as relações fossem construídas de forma mais branda na América portuguesa, em comparação com as pressões sofridas pelos cristãos-novos em Portugal, ainda assim, a vigilância estava presente no cotidiano dessas relações.
\end{abstract}

PALAVRAS-CHAVE: Cristãos-novos; Inquisição; Pernambuco; Vigilância.

\section{Watches of monitoring against New Crhinstian before and during the first visitation of the Inquisition of the capitania of pernambuco.}

ABSTRACT: This article analyzes the presence of the New Christians in the Captaincy of Pernambuco during the 16th century. From the denunciations that resulted from the First Visitation of the Inquisition to Brazil, and the presence of the visitor in the aforementioned Captaincy, between the years of 1593 and 1595, one tries to perceive how the surveillance looks on the new Christians by the population of old Christians, since before the arrival of the representative of the court for these lands. Even if relations were built more soft in Portuguese America, compared to the pressures suffered by New Christians in Portugal, surveillance was still present in the daily life of these relations. KEYWORDS: New Christians; Inquisition; Pernambuco; Surveillance.

\section{Miradas de vigilancia contra los cristianos nuevos antes y durante la primera visitación de la Inquisición a capitanía de pernambuco.}

RESUMEN: El presente artículo analiza la presencia de los cristianos-nuevos en la Capitanía de Pernambuco a lo largo del siglo XVI. A partir de las denuncias que resultaron de la Primera Visitación de la Inquisición a Brasil, y la presencia del visitador en la Capitanía antes citada, entre los años 1593 a 1595, se procura percibir cómo se daban las miradas de vigilancia sobre los cristianos-nuevos por parte población de cristianos viejos, desde antes de la llegada del representante del tribunal por esas tierras. Incluso si las relaciones se construyen en una forma más leve en la América portuguesa, en comparación con las presiones sufridas por los cristianos nuevos en Portugal, aún así, la vigilancia estaba presente en la vida cotidiana de estas relaciones.

PALABRAS CLAVE: Cristianos nuevos; Inquisición; Pernambuco; Vigilancia.

\footnotetext{
*Mestra em História pela Universidade Federal de Campina Grande. Atualmente é doutoranda em História pela Universidade Federal de Pernambuco. Contato: Av. da Arquitetura, s/n, CFCH $11^{\circ}$ Andar, Cidade Universitária, CEP: 50740-550, Recife - PE, Brasil. Email: priscilaandrade28@gmail.com ORCID: https://orcid.org/00000003-3412-6632

**Pós-doutora em História pela Universidade Nova de Lisboa. Atualmente é professora efetiva da Unidade de História e da pós graduação em História da Universidade Federal de Campina Grande-PB, Brasil. Contato: R. Aprígio Veloso, 882, Campus Universitário, CEP: 58429-900 Campina Grande-PB, Brasil. Email: jucieneufcg@gmail.com ORCID: https://orcid.org/0000-0003-1142-7133
} 


\section{Os cristãos-novos no além-mar}

O presente trabalho procura fazer uma análise das microvigilâncias que se apresentaram em Pernambuco com a chegada do representante do Tribunal da Inquisição no final do século XVI, contra os cristãos-novos. Buscando a partir das fontes que se originaram dessa visitação, apresentar uma leitura que demonstra que a produção de relações mais brandas entre cristãos-velhos e novos, não apagou as vigilâncias diárias contra os neoconversos na sociedade analisada. Não apenas durante a passagem do visitador, mas ocorrendo anterior a esse período.

No dia 09 de junho de 1591 chega ao Brasil o Deputado do Santo Ofício Heitor Furtado de Mendonça, aportando na Bahia, onde ficou até 02 de setembro de 1593, depois partindo para Pernambuco, Itamaracá e Paraíba, sucessivamente. Para voltar a Portugal no ano de 1595. O visitador veio ao Brasil como representante oficial da Inquisição para escutar os crimes que se enquadravam na alçada do Santo Ofício e mandar para o Reino as transgressões maiores, principalmente as que se enquadrassem no "crime de judaísmo".

A presença de Heitor Furtado nessas capitanias é inaugural enquanto visitação do Tribunal às terras da América portuguesa, marcando um momento de diversas denúncias e confissões de crimes atinentes ao Santo Ofício. Pensar a chegada do visitador a essas partes é levar em consideração o sentimento que se apossou dos cristãos-novos, que aqui estavam "mais preocupados com o resguardo que a distância de Portugal poderia lhes proporcionar", e assim podiam produzir relações e vivências que não eram possíveis em meio às pressões que se marcavam no reino.

O elevado número de denúncias que se apresentou contra os cristãos-novos ao longo dessa primeira visitação, nos demonstra que não era irrelevante a quantidade de pessoas com descendência neoconversa que embarcaram para esses espaços que vinham sendo ocupados na América portuguesa. Não sendo em vão que diferentes historiadores, tanto clássicos quanto os mais recentes, se interessaram pela temática. Janaina Silva em sua dissertação de mestrado, destaca a notável quantidade de cristãos-novos que embarcou clandestinamente, quando eram proibidos de sair de Portugal: “As fugas eram facilitadas também por uma parcela de funcionários corrompidos, envolvidos no lucrativo negócio movimentado pelas saídas"2. Os degredos também eram uma forma de "carregar" esses indivíduos e outros acusados de diferentes crimes, não apenas para a América portuguesa, mas também para as outras possessões lusitanas. Geraldo Pieroni faz uma análise sobre a pena do degredo, principalmente em Portugal, escrevendo: 
Nos últimos anos do Antigo Regime, várias legislações da Europa adotaram, com regularidade, a condenação às galés, a degredo perpétuo ou temporário, [...] A história do degredo em Portugal adquiriu novos rumos com a expansão marítima dos séculos XV e XVI. Os indesejáveis do Reino podiam doravante ser banidos para as novas terras do além-mar. ${ }^{3}$

Fosse por conta dos degredos, ou por desejo próprio, é esperado que após a conversão forçada e o clima de descontentamento que havia por parte da população para com os cristãosnovos, fosse desejável pelos mesmos a saída do país, e a busca por moradia aonde pudessem encontrar ânimos mais favoráveis para a reconstrução de suas vidas. A vivência em outros espaços e inclusive em possessões além-mar portuguesas era preferível. Anita Novinsky no clássico livro sobre a temática, Cristãos-novos na Bahia, problematiza o preconceito que havia em Portugal, e destaca os traumas produzidos por essas relações estigmatizadas. Transcreve um parágrafo do livro de Antônio Nunes Ribeiro para exemplificar essa desigualdade, o trecho diz:

Tanto que um menino Cristão novo é capaz de brincar com os seus iguais, logo começa a sentir a desgraça de seu nascimento, porque nas disputas que nascem o dos brincos daquela idade, já começa a ser insultado com o nome de Judeu e de Cristão novo. [...] todas essas ações fazem tão grande impressão no ânimo, quer por toda a vida é força que fique mal disposto para quem foi a causa; acresce a este mal que a distinção de Cristão novo, com suma desonra, é publicamente notória, a todos aqueles que vivem naquela Comarca, e que ficará para sempre na sua memória. ${ }^{4}$

Entre os cristãos-novos que preferiram sair de Portugal, tendo em vista que muitos preferiram permanecer no país, na terra aonde suas famílias viviam desde várias gerações passadas. Levemos em conta que as possibilidades de lucro, fossem com o açúcar ou com o pau-brasil, e a presença de uma estrutura mais aberta para uma ascensão social, tornavam o Brasil um destino atrativo para essas pessoas. Sendo, inclusive, de propriedade do cristãonovo Diogo Fernandes, um dos cinco primeiros engenhos de Pernambuco ${ }^{5}$. Discorrendo sobre os criptojudeus ${ }^{6}$ na colônia, Angelo Assis fala:

\begin{abstract}
Assim, não é errado afirmar que, até a última década do séc. XVI, com a chegada do primeiro visitador do Santo Ofício, o licenciado Heitor Furtado de Mendonça, os criptojudeus da colônia, embora procurassem constantemente dar provas públicas de sua real aceitação católica, mantivessem (nem sempre) em segredo, sem maiores ameaças ou perseguições, as práticas e ritos referentes à fé dos antigos parentes judeus. Situação esta que, malgrado os anos de convivência relativamente harmônica ao longo de todo o período do Quinhentos, seria abruptamente interrompida, como vimos, com o desembarque dos representantes da Inquisição na colônia. (ASSIS, 2012, p.309). ${ }^{7}$
\end{abstract}

Podemos então considerar que havia em terras brasileiras uma estrutura que permitia aos cristãos-novos uma maior liberdade em termos de vivência e integração na sociedade de 
cristãos-velhos, com um grau menor de preconceito. Assis também discute que a prova do bom convívio entre "cristãos puros" e a "aflita gente", era a integração dos mesmos em praticamente todos os espaços da economia. Chegando a ocuparem cargos de alto prestígio como os de ouvidor da Vara Eclesiástica, profissional letrado, médico, juiz, etc., além da ocupação desses cargos, percebe-se a prática do matrimônio entre os dois grupos ${ }^{8}$.

Anita Novinsky é outra estudiosa do assunto que vai trabalhar a socialização do cristão-novo com a população de cristãos-velhos, buscando construir espaços na organização social e política, criando raízes na América Portuguesa. Recebiam sesmarias e latifúndios, além de possuir outras propriedades, alcançando posições privilegiadas não apenas economicamente, mas também politicamente, com postos na governança e na administração da colônia. Para os que chegavam sem recursos, quase sempre eram abrigados por amigos e parentes, chegando a receber ajuda financeira desses ${ }^{9}$. Não foram todos os neoconversos que chegavam à essas terras enquanto "homens de posse", como é mais comum ser abordado na historiografia sobre a temática, "muitos vinham com muito pouco, apenas uns poucos pertences que pudessem carregar" 10 .

Exemplificador é o caso de Heitor Antunes, que chega à Bahia com sua família no ano de 1557, e vai ser senhor de engenho, alcançando o posto de "cavaleiro da casa del-rei" com o apoio do governador geral Mem de Sá ${ }^{11}$; ou em Pernambuco o caso de Diogo Fernandes, marido de Branca Dias, que era proprietário do Engenho de Camaragibe; ou ainda o caso da Família Soeiro, que tanto Simão Soeiro era cristão-novo, como sua mulher Maria Alvares era meia cristã-nova, mas eram proprietários de um engenho em Guaiana ${ }^{12}$. Também os irmãos Fernão e Diogo Soares que tinham fazendas e eram mercadores na Vila de Olinda ${ }^{13}$. Mostrando o prestigio que alguns cristãos-novos conseguiram alcançar na América portuguesa, transitavam no Brasil colonial desse período em diferentes espaços da sociedade, e conseguem alcançar posições que entre as pressões e preconceitos existentes em Portugal, não enxergavam enquanto viável.

Uma das formas de interação dos cristãos-novos na sociedade estudada, e também uma estratégia encontrada para se livrar dos olhares vigilantes da população foi casarem-se na América portuguesa com cristãos-velhos. Vejamos o exemplo do alcaide-mor da capitania de Pernambuco, Mateus de Freitas de vinte seis ou vinte sete anos, que era casado com a cristãnova Maria de Herede ${ }^{14}$; outro caso é o da cristã-nova Branca Mendes que casou com Diogo Gonçalves, ouvidor da Capitania de São Vicente"15, e chega a ser denunciada por práticas judaizantes por sua enteada Barbara Castellana. Vejamos ainda a situação de Isabel de Paiva, 
meia cristã-nova ${ }^{16}$, natural da Ilha de Itamaracá que foi casada com Pero Lopes Lobo, capitão da Capitania de Itamaracá, que então servia também de ouvidor, e sua mãe Beatriz Mendes também se casou com um cristão velho, Miguel Alvares ${ }^{17}$.

Interessante ainda é o caso da família de Branca Dias, que vai sofrer diferentes denúncias por "fama pública" de cometer práticas judaicas na região, mas, ainda assim, os seus descendentes casaram entre os mais bem situados da colônia. De suas filhas, apenas uma não casou, duas o fizeram com cristãos-novos e cinco com cristãos-velhos. Seu único filho era casado com uma cristã-velha. A condição de ser falada pela população enquanto judaizante não impediu Branca de inserir sua prole na sociedade, através de "bons casamentos". Uma de suas filhas, Inês Fernandes, é denunciada por práticas judaizantes por mais de uma pessoa, e em uma delas a denunciante vai contar que Inês era casada com o viúvo de sua irmã, Antônio Barbalho "dos da governança desta vila", moradores na freguesia da Matriz. ${ }^{18}$ A irmã falecida se chamava Violante Fernandes, cujo segundo casamento foi com o cristão-velho supracitado, Antônio Barbalho, com quem teve uma filha. Também a neta de Branca, Maria de Paiva, era casada com Agostinho de Olanda, cristão velho e alcaide-mor de Igarassu, cujo filho ocupou o mesmo posto ${ }^{19}$.

Diante do exposto, podemos perceber que as famílias cristãs-novas procuraram estabelecer relação com famílias de cristãos-velhos, com o intuito de melhor se misturarem à população e diminuírem os preconceitos que caíam sobre os mesmos por sua condição de cristãos-novos. Janaina Silva coloca que um número de cem neoconversos havia se casado entre as três capitanias; Pernambuco, Itamaracá e Paraíba, e dentre esse número, sessenta e dois o fizeram com cristãos velhos ${ }^{20}$. Aqueles que se casaram com outros cristãos-novos tiveram filhos que não fizeram o mesmo e assim por diante, o que pode ser observado é a circulação de seus membros em várias instâncias sociais.

Em meio à esperança de fuga das pressões que sofriam em Portugal, e da possibilidade de maior integração nessa sociedade, podemos então imaginar qual foi o sentimento que se apossou das pessoas que tinham ascendência cristã-nova, com a chegada de Heitor Furtado por essas terras. Um alto número entre eles havia vivido no reino e lembravam-se do clima de constante insegurança que se instalara com o restante da população, sabiam ou até haviam vivido, os terríveis acontecimentos que recaíram sobre a população hebreia nos anos anteriores e posteriores a conversão forçada ${ }^{21}$. E como destaca Novinsky, tinham notícias do que acontecia em Portugal, e assim, a respeito da Inquisição, "se algum parente ou amigo 
havia sido preso, quem havia saído no último auto-de-fé, os que haviam sido relaxados a justiça secular,"22.

Sabiam, assim, a visibilidade que o Tribunal dava aos cristãos-novos e aos crimes que se relacionavam com as "práticas judaicas", tinham consciência do risco que corriam apenas por serem cristãos-novos, riscos esses que nunca haviam sido excluídos, mas que ganharam força com a chegada do Visitador. Viveram "todo o período do Quinhentos"23 em convivência até certa medida harmônica, como coloca Assis na citação destacada alguns parágrafos acima, o fim desse século é marcado pelo término dessa relativa segurança, com a chegada do representante da Inquisição.

Ao aportar nas capitanias do Norte, o visitador fez-se valer da burocracia que acompanhava a sua chegada, como de praxe, e da maneira como estava especificado no Regimento da Inquisição. Procurando começar a visita nos bispados, pelas cidades onde o Bispo residia. Avisando de sua chegada com antecedência por meio de carta, para ser recebido pelas autoridades locais, e outras mais burocracias que iremos encontrar detalhadas nos Regimentos:

Depois disto, no primeiro dia santo, que houver mandará publicar nas igrejas do lugar, o dia em que se há de fazer a publicação da visita, com o sermão da fé, que sempre será domingo, ou dia santo; e que portanto encomenda muito ao povo Cristão se ache presente; $\left[\ldots . .{ }^{24}\right.$

De muitas solenidades se marcava a chegada do visitador, como percebemos nas indicações contidas nos próprios Regimentos. De certo, uma situação que aflorava os ânimos entre a população, principalmente entre os que sabiam que podiam, por algum motivo, ser acusados. No dia da chegada, também era feito "procissão solene" com o representante do Santo Ofício, seguido de Missa e de fixação do Edito de Graça e Monitório Geral na porta da igreja principal da cidade:

No dia assinado para a publicação da visita, se fará procissão solene, com as maiores demonstrações de respeito, e autoridade que for possível [...] Logo se começará a missa com toda a solenidade, com diácono, e subdiácono, e haverá sermão da Fé, para o qual o Visitador escolhido pessoas de limpo sangue, de letras, e de conhecida virtude. [...] e tanto que o auto da publicação se acabar, mandará o Visitador fixar na porta principal da Igreja o Edito de graça, e o monitório geral [...] e estarão fixados enquanto durar o tempo da graça. ${ }^{25}$

Ao chegar à Capitania de Pernambuco, o representante da Inquisição estendeu dois períodos de graça para a região, o primeiro destinado para a Vila de Olinda e freguesias mais próximas, e o segundo para a Vila de Igaraçú e freguesias adjacentes. Ao se encaminhar para 
a Capitania de Itamaracá concedeu 12 dias de graça para a região, e em seguida 15 dias para a Paraíba $^{26}$. Por certo, o tempo excessivo que passou na Bahia, e a insistência por parte do tribunal de Lisboa para que o visitador retornasse a Portugal, tendo em vista a demora e o alto custo que já apresentava a viagem para a instituição, impediram Heitor Furtado de conceder os 30 dias de graça que era de praxe que houvesse, em todas as localidades por onde esteve. ${ }^{27}$

Todo o simbolismo que envolvia a chegada do representante da Inquisição às localidades destinadas, desde a procissão, a missa de domingo, o sermão de fé, a fixação do Edital de Graça e do Monitório na igreja da região, tinha por intenção de tocar a sensibilidade da população. Utilizando-se" da "demonstratividade e publicidade", como nos coloca Natale Benazzi $^{28}$, o tribunal vai produzir o terror coletivo instalando em cada família, cada pessoa da América portuguesa, o medo de ser descoberto, de ser denunciado, de ser fruto de vingança de algum inimigo.

Assim o mecanismo de medo coletivo alimentado pelo tribunal havia chegado à América portuguesa. Os crimes que cabiam à alçada ao Santo Ofício eram crimes como: feitiçaria, sodomia, adesão à "seita de Lutero", bígamos, blasfemos, defensores de fornicação, etc. E, entre eles, o que mais recebia a atenção do mesmo era o crime de heresia judaica ou criptojudaismo, cujos sinais podiam ser: guardar o calendário judaico, abster-se de comer porco, jogar fora a água dos potes quando morria alguém em casa, não trabalhar aos sábados, etc.

Entre os crimes denunciados na Primeira Visitação a Pernambuco, o que teve um maior número foi exatamente o de "heresia judaica", fosse contra o sexo feminino ou o masculino, repetindo, segundo Luiz Mott, um quadro verificado desde os primórdios da instalação da Inquisição em Portugal ${ }^{29}$. Era também, junto com luteranismo, um dos crimes pelos quais os suspeitos deveriam ser enviados para serem julgados no tribunal de Lisboa. Em correspondência com o Conselho Geral, é reafirmado para Heitor Mendonça que ele não se excedesse em suas atribuições enquanto representante do tribunal, guardando o regimento da inquisição e o seu manual particular, e que enviasse para o reino apenas os crimes que caracterizassem enquanto ato de judaísmo ou luteranismo, e que possuíssem ao menos uma testemunha digna de crédito $^{30}$.

É necessário fazer uma ressalva que não somente às visitações faziam-se marcar a presença do tribunal Inquisitorial nas colônias portuguesas, havia também outras formas de se manter o clima de medo entre a população. Além das visitas oficiais, o Tribunal encarregava os bispos, vigários e religiosos locais de realizarem diligências, editos, inquirições sobre os 
crimes tidos como mais graves ${ }^{31}$. E no ano de 1579 , o Bispo D. Antônio Barreiros foi o primeiro "representante" da inquisição no país, tendo autoridade para escutar denúncias, abrir devassas, prender culpados e encaminhá-los a Lisboa ${ }^{32}$. Devemos, entretanto, ter em mente que essas eram práticas mais fortemente utilizadas após a primeira visitação de 1591.

A chegada de Heitor Furtado de Mendonça vai dar início a um período de acusações entre inimigos, amigos, vizinhos e até mesmo familiares; de confissões de culpas no confessionário e ao inquisidor, mas principalmente de medo de que seu nome fosse citado na mesa do inquisidor e entrasse para as listas da Inquisição.

Essa vivência cotidiana foi abalada pela chegada do inquisidor por essas terras, como já colocamos anteriormente. Mas porque os cristãos-novos foram tão fortemente denunciados nessa visitação? Quais eram as práticas culturais que se apresentavam em suas vivências e que permitiram o grande número de denúncias sobre os mesmos? Porque nas denúncias tantas situações haviam ocorrido muitos anos antes da chegada do visitador? Já que um alto número das ações que eram tidas como "práticas judaicas" ficaram conhecidas pela população apenas com a chegada do representante inquisitorial e da fixação do Monitório. Seriam todos os denunciados criptojudeus? Havia uma relação concreta de determinados costumes praticados com a religião judaica, ou algumas dessas práticas foram herdadas de gerações anteriores sem serem necessariamente realizadas enquanto atos judaizantes? São problematizações que se apresentam quando pensamos a relação dos indivíduos cristãos-novos com a inquisição, e assim, com as fontes resultadas desse tribunal.

\section{Modos de viver e práticas de vigilância na construção do cotidiano}

Como vimos anteriormente, a chegada do visitador a essas terras marcou-se por uma ruptura das sociabilidades anteriormente vigentes, entre os grupos de cristãos-velhos e cristãos-novos, construídas a partir de fatores bem característicos da vida dos portugueses nessa região. A distância que havia entre a América Portuguesa e Portugal, as dificuldades da chegada nessa localidade, que se unia ao imaginário negativo criado sobre "os trópicos", no continente europeu. A pressão para expansão e povoamento de terras e obtenção de novos espaços, as disputas com grupos indígenas, o baixo contingente de portugueses, as poucas mulheres brancas que se encontravam na região. Todos foram fatores que influenciaram nas relações que se estabeleceram entre os dois grupos. 
Oras, em meio às dificuldades encontradas na região, os estigmas que marcavam as relações entre cristãos-novos e velhos no reino não faziam tamanho sentido de existir por essas localidades, e podemos encontrar isso nas relações familiares que se constituíram. Mas é certo que as diferenças não desapareceram, que as suspeitas se encontravam presente nas vivências cotidianas dessa população, os cristãos-novos detinham as condições necessárias para se encaixarem na colônia e se integrarem à sociedade de cristãos-velhos, mas "tinham consciência de sua desigualdade",33 e do preconceito que herdaram ainda do período de judaísmo livre no reino.

Com a presença de Heitor Furtado de Mendonça, as denúncias chegaram dos mais diferentes espaços; do filho que viu uma atitude da mãe, do vizinho que observou os hábitos da casa do lado, do amigo que escutou uma frase dita em algum momento de informalidade, da negra que trabalhava na casa, do desafeto que esperou uma oportunidade para denunciar o outro. Mas isso era o "normal" em uma visitação inquisitorial, esse era o procedimento de praxe no que diz respeito à inquisição. Estímulo a denúncias de crimes que se remetessem à alçada do tribunal.

Todo o aparato que envolvia o tribunal levava consigo e implantava na população medos que estimulavam as denunciações e confissões, era a produção do "terror coletivo". Natale Benazzi falou sobre a "demonstratividade e publicidade" que se fazia necessária para o objetivo da inquisição de manutenção do "estado de terror" ${ }^{34}$, interessante colocação é feita pela autora ao comparar a ação do tribunal com um super-ego, pelo qual o importante era que tal tribunal fosse temido a ponto de habitar a alma das pessoas, de esmagar as resistências da população frente ao sistema de poder estatal e eclesial que se cria.

Sônia Siqueira, em artigo que discute sobre a relação "poder e inquisição", vai dividir as ações e métodos do tribunal em dois tipos de poderes; o "poder em ato e o poder coercitivo"; o poder em ato era a possibilidade de modificar comportamentos, "formando-se" a partir da persuasão contida nos discursos proferidos nos sermões e também no período de trinta dias, referente ao tempo de graça. Era assim um primeiro exercício de persuasão, construído a partir de toda a atmosfera de medo que o tribunal criava na população. Já o poder coercitivo era o uso da força, da violência, "com o fim de modificar as condutas, mobiliza, fere, aprisiona, mata" 35 , para a autora, o Santo Ofício privava os homens da liberdade de crer, de pensar e de agir.

O Santo Ofício era um tribunal que agia contra os delitos de fé, não era mais "violento" que as outras instituições e penitências da época, pelo contrário, bem sabemos a 
violência que envolvia os suplícios na justiça regular de toda a Europa nesse período. Mas sua ação se dava em uma esfera mais íntima do ser humano, apresentava-se na crença e consciência de toda a população, pois o mesmo tinha alçada sobre todos os cristãos do reino, era um tribunal de "juízes da alma" ${ }^{, 36}$. Todo o aparato que carregava consigo, inspirava a insegurança necessária para que as denúncias e confissões chegassem à ordem do dia. Ângela Viera Maia, em livro sobre a primeira visitação, faz a seguinte colocação:

[...] as denúncias e as confissões apresentadas diante da Mesa do Visitador são indícios de medo: medo de ser acusado ou de ser suspeito. Esse medo que levava homens e mulheres a confessar, denunciar e apontar levantou suspeitas, desorganizou a sociedade desestruturando a convivência das pessoas na Colônia, (MAIA, 2003, p. 53).

Podemos encontrar essa situação também em casos de pessoas que iam denunciar seus familiares e na própria denúncia já justificavam as atitudes dos mesmos; isso aconteceu em diferentes denúncias no período que o visitador esteve em Pernambuco. Como também é citado por Angelo Assis, quando estuda o caso de Ana Rodrigues e sua família, na Bahia:

[...] levando os membros da família a comparecerem em peso à mesa do Tribunal, buscando, dentro do possível, amenizar e contornar as acusações contra os Antunes relatadas ao visitador. Objetivo primeiro: afastar a descuidada matriarca do centro das atenções do Santo Ofício, amortecendo, em consequência, as desconfianças sobre o restante da família (2012, p. 238).

Contudo, inspirar as denúncias e confissões a partir de todo o aparato de "medo", como fala Ângela Maia, não significa necessariamente que todos os indivíduos se dirigiram à mesa do visitador em detrimento da pressão que o momento impunha à população. Existiram casos de pessoas que denunciaram outras e que nutriam algum desafeto, como aconteceu com Bento Teixeira, denunciado por Jorge Thomaz por fazer "coisas de judeus", e que durante sua denúncia conta ter tido desafeto com o denunciado quatro anos antes ${ }^{37}$. Certo que Thomaz não atribui ter se encaminhado a Heitor Furtado por conta dos desafetos que tinha com Bento Teixeira, mas fica a brecha para pensarmos na intenção do denunciante. Precisamos ter cuidado para não generalizar as situações e o que motivou essas denúncias, pois cada caso tinha suas especificidades.

Mas essa convivência entre cristãos-velhos e novos se dava realmente tão tranquila assim? Não estamos negando as relações mais brandas que se produziam entre os cristãosvelhos e os neoconversos por essas terras, estamos nos perguntando até que ponto as boas relações apagavam o estigma que assolava os cristãos-novos, estigma esse carregado já do reino e desde épocas anteriores. Novinsky falou; "contudo, tinham consciência da sua 
desigualdade. Eram homens que se moviam dentro de uma sociedade que sabiam não fazer parte" 38 . Oras e porque nas denunciações contra os mesmos podemos observar que são repetidas por diferentes vezes, as frases: "era de fama pública que ela viera degredada para este Brasil pela Santa Inquisição"39, "o qual dizem ter raça de cristão novo"40, "e ele denunciante se escandalizou de ver aquilo por eles serem cristãos novos"41, "e por serem da nação segundo a conta em que ele os tem e são tidos lhe pareceu mal as ditas palavras"42.

E porque lembranças de situações que ocorreram tantos anos atrás? Como podemos encontrar denúncias de casos que se passaram já havia quarenta, trinta, vinte anos. Sabemos que muitas práticas que eram consideradas "coisas de judeus" ficaram conhecidas pela população a partir da chegada do visitador e da fixação do Monitório e Edito de Fé, situação que ajudou a motivar recordações de determinados acontecimentos que se deram tempos antes. Mas se você observa algo é porque aquela situação lhe chamou a atenção, talvez por ser um hábito diferente do que você é acostumado, ou talvez por ser praticado por alguém que já lhe inspirava determinada suspeita. As pessoas não saíam do reino e chegavam a essas terras apagando toda a memória de conflitos e vivências que se estabeleciam por lá, elas há carregavam consigo ao longo da viagem. Fazendo-nos assim indagar até que ponto essas nuances de boa coabitação invalidaram certo tipo de vigilância sobre os indivíduos que já eram propensos a serem suspeitos.

Seriam as vigilâncias mantidas no cotidiano dessas populações? Pensamos aqui não apenas nas macrovigilâncias exercidas pela presença do tribunal inquisitorial, mas também e talvez principalmente, nas microvigilâncias, aquelas que são produzidas no dia a dia, na imperceptibilidade por parte de quem comete o ato. Situações que se construíram antes da chegada do visitador, olhares suspeitos que já existiam antes que o Tribunal Inquisitorial mandasse um representante e Heitor Furtado de Mendonça aportasse no norte açucareiro.

Michel Foucault, em Vigiar e Punir, pensa nos micropoderes, na ideia de uma vigilância constante que existe a partir dos diferentes e menores espaços da sociedade, necessários para que o funcionamento do sistema panóptico seja possível. É "no exercício cotidiano da vigilância"43, trabalhado pelo autor, que estamos interessados. Foucault fala de uma vigilância que se instituiu do século XIX em diante, mas as microvigilâncias não estavam excluídas desse período estudado. Não pensamos aqui, em pleno final do século XVI, que um sistema como o panoptismo estivesse instituído, mas temos vigilâncias cotidianas que se encontravam na vivência da população, e ganharam destaque com a chegada do visitador a América. 
Vejamos, por exemplo, a denúncia de Felippe Cavalcanti, que se dirigiu à mesa do visitador no tempo de graça concedido à Vila de Olinda, em 16 de novembro de 1593. Sua denúncia baseia-se na pública fama de uma possível esnoga ${ }^{44}$ que havia no engenho de Camaragibi, por volta de quarenta anos antes do período que se encaminha ao representando do tribunal, o engenho era de posse do casal Diogo Fernandes e Branca Dias. Fala assim o denunciante: "e era fama publica nesta terra geralmente dito por todos assim nobres e principais como mais gente e povo que no dito Camaragibe havia esnoga onde se ajuntavam os judeus dessa terra e faziam suas cerimonias" 45 , Cavalcanti, assim, observava a frequência e a época que alguns cristãos-novos se dirigiam a Camaragibi:

e que ele denunciante viu três ou quatro anos o Reo nas ditas luas novas de agosto ir o dito Anrique Mendez com sua família e casa pela sobredita maneira ao dito Camaragibi, e na companhia do dito Anrique Mendez iam também Antonio Diaz, e seu cunhado de alcunha Alma de Burzeguis, o qual se gabava que fora batizado em pé, todos cristãos novos ${ }^{46}$.

Observemos que a pública fama do engenho já existia muito antes da chegada de Heitor Furtado no Brasil, e as pessoas que o frequentavam eram observadas e vigiadas pela população desde esse período. Felippe Cavalcanti não apenas lembrou-se da época em que as visitas se davam na possível esnoga, como também quem eram os cristãos-novos que ele se atentou que frequentaram Camaragibe. Oras, era uma situação que havia ocorrido há, em média, quarenta anos passados, parte dos acusados já havia falecido e outros não moravam mais na Capitania. Porque lembrava o denunciante de tantos detalhes dos acontecimentos? De certo, toda a situação não pareceu tão sem importância para ele e para as pessoas que comentavam sobre o possível espaço de culto ao judaísmo em Camaragibi.

Na mesma denúncia, Felippe Cavalcanti falou de Antonio Diaz Dalcunha, cristãonovo ao qual o denunciante observou que "viu alguns sábados que nele atentou sendo dias de trabalho não ir ao trabalho e serviço das roças e neles andar vestido do melhor vestido de festa que tinha e nos dias domingo e dias santos ir a roça" ${ }^{47}$, esse relato de Cavalcanti havia se passado entre quarenta e quatro ou quarenta e cinco anos antes, ele não tinha mais notícias do destino de Antonio Diaz, pois não entra nesses detalhes com o visitador, entretanto, o ato de guarda do sábado, observado há tanto tempo, não havia sido esquecido pelo mesmo.

Uma forma de exercer esse tipo de vigilância dava-se não apenas na convivência direta, mas também na noção de privacidade na colônia, ou da falta dela, visto a partir da perspectiva moderna do termo. É assim importante compreendermos que a ideia de privacidade no Brasil, em tempos que este era possessão de Portugal, é muito distinta do que 
conhecemos enquanto tal0. Não havia um interior doméstico privado na forma como convivemos hoje. Em texto presente no primeiro livro da coletânea História da Vida Privada no Brasil, Ronaldo Vainfas elucida:

As condições histórico-sociais do "viver em colônias" (Vilhena) conspirava, pois, contra a ocorrência de qualquer privacidade no Brasil dos primeiros séculos [...] Faz-se necessário, portanto, divorciar, no caso da América portuguesa, a ideia de privacidade da ideia de domesticidade. As casas coloniais fossem grande ou pequenas, estavam abertas aos olhares e ouvidos alheios, e os assuntos particulares eram ou podiam ser, com frequência, assuntos de conhecimento geral. (VAINFAS, 1997. p. 226- 227).

Principalmente nos primeiros séculos de colonização, não havia a conhecida distinção entre público e privado, como apresenta Vainfas. Também Leila Algranti, em texto presente na mesma coletânea, diz que essa distinção não se aplica ao período colonial, antes do final do século XVIII e início do $\mathrm{XIX}^{48}$. Era um mundo deveras diferente do que conhecemos, inclusive no que se refere aos espaços de moradia e aos modos de habitação.

O modo próprio de privacidade que encontramos na colônia permitiu que as pequenas vigilâncias se dessem de forma mais efetiva entre a sociedade, inclusive com a figura do cristão-novo, situação que certamente fortaleceu o índice de denunciações ao visitador. Elias Lipiner, em seu livro sobre os judaizantes na primeira visitação, atenta para a relação entre a configuração das casas e as denúncias ao Tribunal, o autor fala o seguinte sobre essas moradias:

As casas, no período colonial, além de situadas em ruas estreitas e serem de meias paredes, comunicavam-se frequentemente pelos quintais, permitindo falarem-se as vizinhas das janelas fronteiras ou traseiras confinantes, e expondo aos olhos dos curiosos a intimidade de seus moradores. (LIPINER, 1969, p. 68).

Oras, se os olhares atentos já existiam e se juntavam com o falatório sobre a ação de determinados indivíduos, podemos encontrar um número maior de denunciações quando a escassa privacidade que se dava, não apenas nas relações, mas também nas configurações das moradias, permitindo uma maior observação e vigilância sobre a vida do outro. Seria o caso da denúncia contra Inez Fernandes, cristã-nova denunciada por sua vizinha, Antonia Bezerra, em função da guarda do sábado.

Antonia Bezerra foi à mesa do Visitador em 12 de novembro de 1593, e contou que quando se casou com Antonio Barbalho, por volta de sete anos antes, mudou-se para uma casa que fazia fronteira com a residência de Baltasar Leitão e de sua mulher Inez Fernandes, já falecida no momento da denúncia. E que pelas janelas de sua casa podia ver o que 
acontecia na casa da denunciada, passando a observar o que fazia Inez, depois que outra moradora da Vila lhe disse para atentar ao que se passava na casa Baltasar Leitão;

[...] e de dentro de sua casa pelas janelas vê o que se faz dentro na casa do dito Balthesar Leitão e quando ela casou e veio para a dita era viva Ines Fernandes cristã nova mulher do dito Balthesar Leitão [...] e viu que a dita Ines Fernandes em todo o dito tempo de três anos os sabados que eram dias de trabalho guardava estando sempre neles deitada em uma rede lendo por livros sem fazer outro nenhum serviço ${ }^{49}$.

Atentemos que a denunciante observava Inez Fernandes de dentro de sua própria casa, a partir de uma janela que lhe permitia ver a residência da outra. E, em sua denúncia, permitiu que nós passássemos a ter uma melhor noção de como eram as estruturas dessas residências e os espaços entre uma casa e outra. Leila Algranti faz um breve relato sobre as habitações nos primeiros séculos de colonização portuguesa:

[...] nos três primeiros séculos da colonização, o aspecto das moradas apresenta-se bastante simples e pobre, [...] Encontramos, assim, certa homogeneidade nas construções urbanas, como casas de tamanho mais reduzido, de apenas um andar, nas quais predominavam os materiais disponíveis na região, como barro, madeira ou pedras. Os sobrados e as vivendas, ocupados pelos membros da elite, surgiram mais tarde, em consequência da diversificação da economia e do crescimento urbano. (ALGRANTI, 1997, p. 90).

As moradias não se apresentavam com luxo, e nem com espaços para a construção de uma privacidade que permitisse a realização de práticas totalmente escondidas, mas também as sociabilidades não contribuíam para esse tipo de vivência. O baixo número populacional, Olinda, por exemplo, que era o centro da Capitania de Pernambuco no período, tinha cerca de 200 vizinhos $^{50}$-, além das dificuldades da região, colaboravam para uma relação mais intensa.

Também as vilas e freguesias eram espaços de passagem, tanto de proprietários de engenhos e fazendas, que precisavam de abrigo, quanto de mercadores, principalmente nas principais vilas, “dentro da vila de Olinda habitam inumeráveis mercadores com suas lojas abertas, colmadas de mercadorias de muito preço, de toda sorte, em tantas quantidades que semelha uma Lisboa Pequena"51. Apesar de ser necessário o devido cuidado ao analisar as palavras de Ambrósio Brandão, que procurava enaltecer as características do lugar, podemos perceber que essas eram situações que contribuíam para os olhares curiosos e vigilantes sobre a população presente, e assim sobre os cristãos-novos. 
Figura 1: casa térrea simples

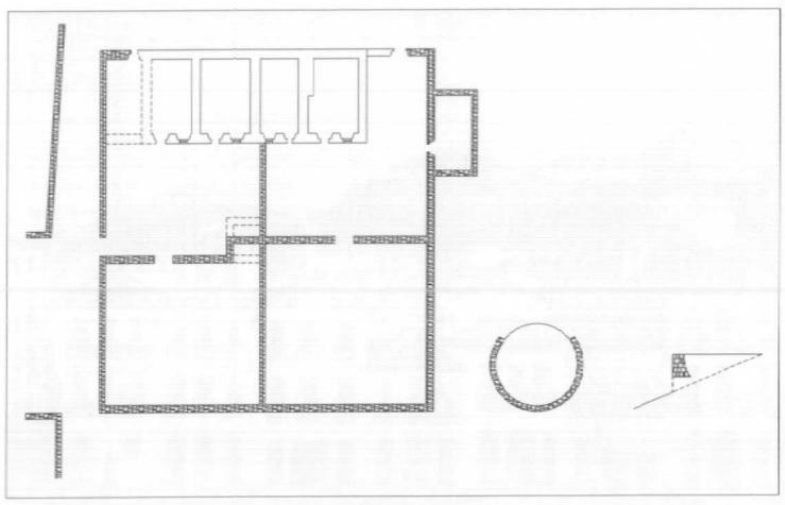

Fonte: Casa de Encosta de Morro segundo Sylvio de Vasconcelos apud. ALGRANTI, 1977, p. 88

Contudo, não apenas as casas térreas podiam ser encontradas nesse período. Nas denúncias que se apresentaram contra a matriarca Branca Dias, moradora na vila de Olinda com sua família, encontramos diferentes menções ao primeiro andar de sua residência; "e se recolhiam em cima no sobrado [...] e que algumas vezes depois que abriam a porta e desciam para baixo" 52 ; "chamava acima do sobrado as ditas suas filhas [...] e todos iam então acima jantar" ${ }^{, 53}$. De certo, por conta do bom andamento dos engenhos de cana-de-açúcar da região, que consequentemente influenciava na prosperidade das Vilas, “o Jesuíta Fernão Cardim, em 1584, afirmou que a Capitania de Pernambuco possuía 60 engenhos e uma produção de açúcar de 200 mil arrobas, além de mais de 45 navios que aportavam nos arrecifes" ${ }^{~}$.

Mas, mesmo com a prosperidade de Pernambuco nesse período, as casas eram simples, construídas muito próximas umas das outras, as paredes eram baixas, os quintais "eram circundados por muros baixos que delimitavam o espaço doméstico" ${ }^{55}$, as ruas eram estreitas, as vilas e povoações eram pequenas, e com isso, todos se conheciam, sabiam quem era quem. As sociabilidades também se davam na rua, favorecendo os olhares vigilantes, as histórias corriam, a "pública fama" passeava pelos espaços, ganhava vez na voz dos colonos, nos murmurinhos e fofocas do dia a dia. Produziam-se também enquanto "veículos de circulação de uma tensão que permeava as relações entre alguns cristãos-novos e velhos" "56.

$\mathrm{Na}$ denúncia de Antônia Bezerra podemos observar tanto as relações quanto os espaços de vigilância, os olhares sobre Inez Fernandes já se davam de outros tempos, e os comentários já estavam presentes entre a população, pois a denunciante veio a dizer que passou a vigiar a casa de sua vizinha porque Ana Duarte já havia avisado que o fizesse, e também por ser Inez Fernandes cristã-nova, ela "de propósito atentou sempre" ${ }^{, 57}$. Como antes observamos, as desconfianças e vigilâncias estavam presentes na sociedade desde antes da 
chegada do visitador, a distância entre a colônia e o reino não excluiu o preconceito que existia para com os cristãos-novos.

Também Catharina da Mota denunciou a cristã-nova Catharina de Figueiredo na Capitania de Itamaracá, em função da guarda dos sábados - costume deveras denunciado ao visitador -, a denunciante se dirige à presença de Heitor Furtado no dia 09 de dezembro de 1594, ainda no Tempo de Graça que é destinado a essa capitania, e conta que:

[...] sendo vizinha fronteira de Caterinha de Figueredo tida e avida por cristã nova mulher de Salvador de Miranda [...] para ali no qual tempo por serem vizinhos e terem muita conversação e comunicação e ela denunciante ir muitas vezes na casa da dita Caterina de Figueredo que era a vista e perto da sua $[\ldots]^{58}$.

Catharina da Motta dirigiu-se ao visitador para relatar situações que se passaram anterior quatro ou cinco anos da chegada do mesmo a Itamaracá, e que viu algumas vezes, no período de dois meses que esteve morando em uma fazenda, que era próxima da morada de Catharina Figueiredo. A denunciante visitou em diferentes momentos a casa da acusada, em um período de apenas dois meses em que esteve residindo naquele espaço. Ao ponto de ter acesso à rotina da mesma, pois conhecia os costumes, inclusive da vestimenta que a acusada tinha durante a semana, e que, segundo a denunciante, se modificavam aos sábados,

nos quais atentou sendo dias de semana e de trabalho que a dita Caterina de Figueredo se vestiu neles do melhor vestido que tinha [...] e que nos outros dias da semana não vestia aqueles ditos vestidos senão outros mais usados e somenos mas em alguns deles vestia também roupa lavada ${ }^{59}$.

Observou também que aos domingos, dias de descanso, antes de ir à missa, Catharina Figueiredo costumava cuidar da horta, e até mesmo que, em um desses domingos, a acusada foi lavar uma saia de pano, sem haver necessidade de ser lavada, pois ela tinha "sete ou oito negras" que podiam fazer isso por ela. Interessante na denúncia de da Motta é que ela logo justifica a amiga como uma "boa cristã", que ia à missa aos domingos e ia "muito bem arrumada", com roupas de seda que ela não a via usar aos sábados. Entretanto, ela desconfia das ações de Catharina Figueiredo, pois "por dizerem ser cristã nova lhe pareceu mal estas coisas" $" 60$.

As civilidades davam-se de maneira diferente quando pensamos na vivência que ocorria nas fazendas e engenhos, e no cotidiano que se apresentava nas Vilas, locais com maior aglomeração de pessoas. Mesmo que o contingente populacional nesse período não fosse alto nessas regiões, ainda assim, a forma das relações era distinta. Afinal as distâncias 
percorridas para se chegar a outras residências e aos próprios vilarejos eram bem maiores. Nos espaços mais rurais não vamos ter as características de ruas estreitas com casas aglomeradas, como encontramos em Olinda, por exemplo. A própria Catharina da Mota diz que ia sempre à casa de Catharina Figueiredo por conta da proximidade das residências, deixando a entender que não havia tantas residências nas imediações, que permitisse uma rede de sociabilidade vasta. Não esqueçamos também que eram espaços onde o número de negros e indígenas era maior que o de pessoas de origem portuguesa.

Figura 2: exemplo de uma propriedade rural, aonde se desenvolvia a vida íntima de seus moradores.

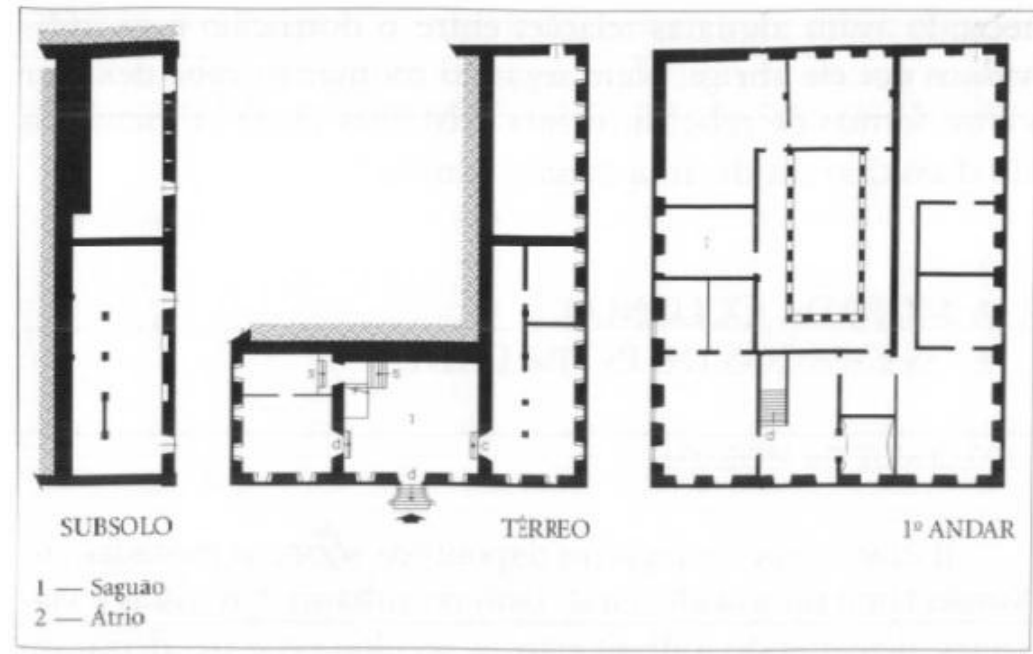

Fonte: Engenho Caboto, Candeias. apud. ALGRANTI, 1977, p. 89

A acusada não diz se descobriu que aquelas práticas eram tidas como atos judaicos no período da chegada do visitador, ou se anterior a isso, mas elas lhe chamaram a atenção quatro ou cinco anos antes de Heitor Furtado visitar Itamaracá. As vigilâncias ocorriam, estavam presentes no cotidiano da população, nos atos ínfimos, cometidos, seja de forma inocente, seja por conta da falsa ilusão de uma segurança.

Não estamos afirmando que tanto Catharina de Figueiredo quanto Inez Fernandes ou as outras mulheres acusadas eram necessariamente criptojudaicas e cometiam os atos pelos quais estavam sendo denunciadas, como uma cerimônia intencionalmente judaica, nem todas as pessoas denunciadas - os cristãos-novos como um todo -, estavam produzindo práticas enquanto seguidores de algum judaísmo possível, mas os olhares e desconfianças se davam 
por serem cristãos-novos, e, por assim o serem, todas as suas atitudes eram suspeitas, principalmente as que fugiam do "normal" aos olhos do denunciante.

Mas, por outro lado, pensamos que onde há vigilâncias também pode haver resistências, as pessoas não necessariamente se prendem a redes de proibições sem possibilidade de ação. Não enxergamos que os olhares atentos engessam os indivíduos de tal modo que não possa ser encontrada uma possibilidade de escape, de burla, frente ao que lhe foi imposto e lhe desagrada, comprime-lhe. E, se é assim, alguns cristãos-novos produziram sim práticas referentes à crença de seus ancestrais, mesmo em meio às proibições que lhes eram impostas e as microvigilâncias que se construíam no dia a dia dessa população.

Pudemos perceber a partir da análise das fontes que se originaram da chegada do representante inquisitorial em fins do século XVI, que a saída dos cristãos-novos de Portugal, para a possessão portuguesa nas Américas, não excluiu os preconceitos existentes contra os descendentes de judeus. A passagem pelo Atlântico não apagou os estigmas que se construíram na população portuguesa, e por tal, os olhares de microvigilância puderam ser observados nas denúncias feitas ao visitador, com a descrição de situações que ocorreram anterior a 1593, e que chamaram a atenção por serem os denunciados de origem neoconversa. A vigilância não passou a ocorrer apenas com a chegada de Heitor Furtado de Mendonça, ela se apresentava no dia-a-dia da capitania, mesmo que houvesse uma construção da sociabilidade de maneira mais branda, que a existente no país lusitano.

\section{Notas}

\footnotetext{
${ }^{1}$ SILVA, 2007, p.14.

${ }^{2}$ SILVA, 2007, p. 42.

${ }^{3}$ PIERONI, 2000, p. 30.

${ }^{4}$ Apud, NOVINSKY, 1972, p. 61-62. Gráfia atualizada; Antônio Nunes Ribeiro Sanches, Christãos Novos e Christãos Velhos em Portugal, Lisboa, 1956, p. 6.

${ }^{5}$ SILVA, 2007, p. 41.

${ }^{6} \mathrm{O}$ termo criptojudeu ou marrano, tem diferentes debates na historiografia sobre a temática, Elias Lipiner vai descrever o que eram criptojudeus em dicionário sobre os termos inquisitoriais: "Os judeus que, impelidos do terror, aceitaram o batismo e tornaram-se pseudo-cristãos, vivendo como católicos, mas prestando culto no seu íntimo a Lei velha.” (LIPINER, 1977, p. 53). Para conhecer melhor o tema ver: SARAIVA, António José. Inquisição e cristãos-novos. Editorial Estampa, Lisboa, 5 edição, 1985.

${ }^{7}$ Grifos Nossos.

${ }^{8}$ ASSIS, 2002, p.51.

${ }^{9}$ NOVINSKY, 1972, p. 60.

${ }^{10}$ SILVA, 2007, p. 43.

${ }^{11}$ ASSIS, 2011, p. 357.

${ }^{12}$ PRIMEIRA, 1984. Confissão de Guiomar Soeira, Filha de Simão Soeiro, Cristão novo, Na Graça. p. 108 109.

${ }^{13}$ Idem, André Pedro contra André Gomes e Antonio da Costa, p. 258 - 260.
} 
${ }^{14}$ PRIMEIRA, 1984, Mateus de Freitas [de Azevedo] contra João Nunes e Bento Teixeira, p. 67- 70.

${ }^{15}$ Idem, Barbara Castellana contra Branca Mendes, p. $99-102$.

${ }^{16}$ Meio cristão-novo era uma nomenclatura usada para alguém que tinha um de seus pais, o pai ou a mãe, enquanto cristão-novo.

${ }^{17}$ Idem, Isabel de Paiva contra Guiomar Soeiro, p. 371-373.

${ }^{18}$ Idem, Antonia Bezerra contra Inez Fernandes, p. 65- 66.

${ }^{19}$ Idem, Maria de Paiva contra André Pedro flamengo, p. 253 - 254.

${ }^{20}$ SILVA, 2007, p. 60.

${ }^{21}$ Para melhor leitura sobre esses acontecimentos ver: MORENO, Humberto Baquero. Tensões e conflitos na Sociedade Portuguesa em Vésperas de 1492. In: Novinsky, Anita (coord.). Ibéria judaica: roteiros da memória. São Paulo: Edusp, 1996.

${ }^{22}$ NOVINSKY, 1972, p. 110.

${ }^{23}$ ASSIS, 2012, p. 309.

${ }^{24}$ Regimento do Santo Ofício da Inquisição, dos reinos de Portugal. In. Revista do Instituto Histórico e Geográfico brasileiro. Rio de Janeiro, ${ }^{a}$ 157, N $^{\circ}$ 392, jul/set 1996, Livro I, Titulo I. P. 717-721. Regimento de 1640.

${ }^{25}$ Regimento do Santo Ofício da Inquisição, dos reinos de Portugal. In. Revista do Instituto Histórico e Geográfico brasileiro. Rio de Janeiro, ${ }^{a}$ 157, № 392, jul/set 1996, Livro I, Titulo I. P. 717-721. Regimento de 1640 .

${ }^{26}$ PRIMEIRA, 1984, p. 10, 138, 360, 392.

${ }^{27}$ Para mais informações sobre os excessos de Heitor Furtado tanto em abuso de poder, quanto em tempo de visitação consultar: LIPINER, Elias. Os judaizantes nas capitanias de cima: estudos sobre os cristãos-novos do Brasil nos séculos XVI e XVII. São Paulo: Brasiliense, 1969; p. 21-22. E também o trabalho dissertativo de OLIVEIRA, Halyson Rodrygo Silva de. Mundo de Medo: Inquisição e Cristãos-novos nos espaços coloniais. Natal; 2012; p. 51-53.

${ }^{28}$ BENAZZI, 2002, p. 14.

${ }^{29}$ MOTT, 2005, p. 309.

${ }^{30}$ LIPINER, 1969, p. 19.

${ }^{31}$ NOVINSKY, 1972, p.110

${ }^{32}$ CALAINHO, 2006, p. 71.

${ }^{33}$ NOVINSKY, 1972, p. 61.

${ }^{34}$ BENAZZI, 2001, p. 14

${ }^{35}$ SIQUEIRA, 2008, p. 87.

${ }^{36}$ BENAZZI. 2001, p. 16.

${ }^{37}$ PRIMEIRA, Antonio da Rosa contra Bento Teixeira, 1984, p. 291-293.

${ }^{38}$ NOVINSKY, 1972, p. 61.

${ }^{39}$ Grafia atualizada; Idem, p. 32-33.

${ }^{40}$ Idem, p. 88-89.

${ }^{41}$ Gráfia atualizada; Ibdem, p. 18-21

${ }^{42}$ Gráfia atualizada; Ibdem, p. 113. A nação ao qual o denunciante se refere, é a "nação" de cristãos novos.

${ }^{43}$ Idem, p. 210.

${ }^{44} \mathrm{Em} \mathrm{ABC}$ do pensamento judaico Hugo Schlesinger vai colocar que Esnoga era a "denominação dada à sinagoga pelos cristãos novos de Pernambuco" - (SCHLESINGER, 1969, p. 39).

"Sinagoga - Textualmente: convocação ou assembleia. Palavra de origem grega. Lugar onde se celebra o culto religioso israelita. Templo. Casa de Deus; A sinagoga é o centro religioso, cultural e social da comunidade judaica." - (SCHLESINGER, 1969, p; 134).

${ }^{45}$ Grafia atualizada. PRIMEIRA, 1984, p. $75-77$

${ }^{46}$ Grafia atualizada; PRIMEIRA, 1984, p. 75-77.

${ }^{47}$ Grafia atualizada, Idem, p. 75-77.

${ }^{48}$ ALGRANTI, 1997, p. 89.

${ }^{49}$ Grafia atualizada; Antonia Bezerra contra Inez Fernandes, idem, p. 65- 66.

${ }^{50}$ SOUZA, 2007, p. 83

${ }^{51}$ BRANDÃO, Ambrósio Fernandes. Diálogos das Grandezas do Brasil. $3^{\circ}$ ed. Recife: FUNDAJ, Editora Massangana, 1997. Apud. SILVA, Janaína Guimarães da Fonseca e. Modos de pensar, maneiras de viver: Cristãos-novos em Pernambuco no século XVI. Dissertação apresentada ao Programa de Pós-Graduação em História da UFPE. Recife, 2007. 


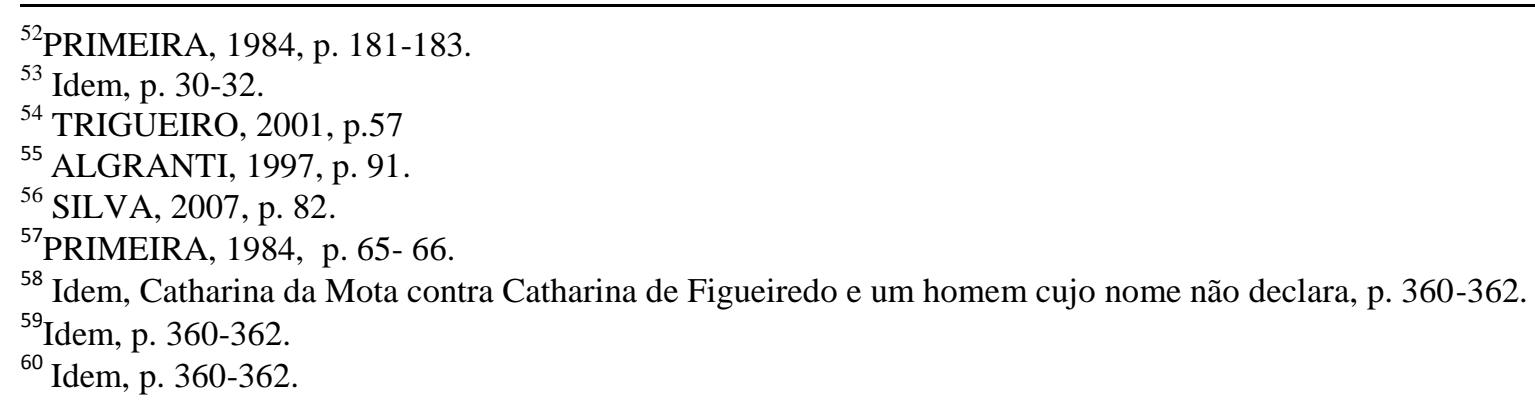

\section{Referências bibliográficas}

ALGRANTI, Leila Mezan. Famílias e Vida Doméstica. In: NOVAIS, Fernando A. (coordenador geral) e SOUZA, Laura de Mello (org.). História da vida privada no Brasil: cotidiano e vida privada na América portuguesa. São Paulo: Companhia das Letras, 1997. ASSIS, Angelo Adriano Farias de. Macabeias da colônia: Criptojudaísmo Feminino na Bahia. São Paulo: Alameda, 2012.

BENAZZI, Natale; D’AMICO, Matteo. O Livro Negro da Inquisição: A reconstituição dos grandes processos. Lisboa: Âncora, 2001.

CALAINHO, Daniela Buono. Agentes da fé: familiares da inquisição portuguesa no Brasil Colonial. Bauru, SP. Edusc, 2006.

LIPINER, Elias. Santa Inquisição: terror e linguagem.Rio de Janeiro: Documentário, 1977. MAIA, Ângela Maria Vieira. Â Sombra do Medo: Cristãos-Velhos e Cristãos-Novos nas Capitanias do Açúcar. Rio de Janeiro: Idealizarte, 2003.

MOTT, Luiz. Filhos de Abraão \& Sodomia: cristãos-novos homossexuais nos tempos da Inquisição. In: GORENSTEIS, Lina \& CARNEIRO, Maria Luisa Tucci (org.), Ensaios sobre a intolerância: Inquisição, Marranismo e Anti-semitismo. São Paulo: Humanitas, 2005.

NOVINSKY, Anita W. Cristãos-Novos na Bahia. São Paulo: Editora Perspectiva/Editora USP, 1972.

PIERONI, Geraldo. Os excluídos do Reino: A inquisição Portuguesa e o degredo para o Brasil Colônia - Brasília: Editora Universidade de Brasília, 2000.

PRIMEIRA, Visitação do Santo Oficio as Partes do Brasil: Denunciações e confissões de Pernambuco 1593-1595. Prefácio de José Antônio Gonçalves de Mello. Recife, FUNDARPE. Diretoria de Assuntos Culturais, 1984. 509+158p. Il. (Coleção Pernambucana $2^{\mathrm{a}}$. Fase, 14).

Regimento do Santo Ofício da Inquisição, dos reinos de Portugal. In. Revista do Instituto Histórico e Geográfico brasileiro. Rio de Janeiro, ${ }^{a}$ 157, No 392, jul/set 1996, Livro I, Titulo I. P. 717-721. Regimento de 1640.

SCHLESINGER, Hugo. Pequeno ABC do pensamento judaico: Síntese de definições dos valores religiosos, morais e éticos do judaísmo. Editora B'NAI B'RITH, São Paulo, 1969.

SILVA, Janaína Guimarães da Fonseca e. Modos de pensar, maneiras de viver: Cristãosnovos em Pernambuco no século XVI. Dissertação apresentada ao Programa de PósGraduação em História da UFPE. Recife, 2007.

SIQUEIRA, Sonia A. O Poder da Inquisição e a Inquisição como Poder. Revista Brasileira de História das Religiões - Dossiê Identidades Religiosas e História. São Paulo, ano I, n. 1, p. 84-93, 2008. 
TRIGUEIRO, Tatiane de Lima. Um caso de "feitiçaria" na Inquisição de Pernambuco. Dissertação de mestrado apresentada ao programa de pós-graduação em História da Universidade Federal de Pernambuco, Recife, 2001.

VAINFAS, Ronaldo. Moralidades Brasílicas: Deleites sexuais e linguagem erótica na sociedade escravista. In: NOVAIS, Fernando A. (coordenador geral) e SOUZA, Laura de Mello e (org.). História da vida privada no Brasil: cotidiano e vida privada na América portuguesa. São Paulo: Companhia das Letras, 1997. 